\title{
Journal Of Contemporary Urban Affairs
}

2019, Volume 3, Number 2, pages 95- 98

\section{Reformation of Slums \\ * BSC. Modupe Odemakin 1 (D), MSc. Abiola Ayopo Abiodun ${ }^{2}$ \\ 1 and 2 Faculty of Architecture, Eastern Mediterranean University, Famagusta, Cyprus E mail; 17500572@students.emu.edu.tr E mail: abiola.abiodun@cc.emu.edu.tr}

\section{ART I CLE INFO:}

Article history:

Received 16 May 2018

Accepted 20 June 2018

Available online 18 October

2018

Keywords:

Reformation;

Slums;

Infrastructure;

Growth:

Technology;

Environment;

Investment.

This work is licensed under a Creative Commons Attribution - NonCommercial - NoDerivs 4.0 "CC-BY-NC-ND"

\begin{abstract}
A B S T R A C T
The world keeps getting better in every aspect including housing and infrastructure and the growing technology keeps improving affordable housing, but the chances of completely eradicating slums will remain slim because there will always be people unable to afford better housing than slums have to offer. Aside from the fact that a slum is known as being the residential environment with the poorest living conditions, it is also known for various negative activities and a relatively high crime rate. The notion that an environment greatly influences an individual holds out the necessity to create better-living conditions that will in time nurture and improve the individual. To this end, the reformation of slums should be a priority. In as much as these slums cannot be eradicated completely, physical upgrading of slums with improved street networks, better building materials, better air quality, easy access to basic municipal services, improves natural ventilation, natural lighting and better drainages will prove to make positive changes economically, socially and reduce crime rates in many cities. It will also improve the physical general wellbeing of communities. In conclusion, a community, no matter how small has the ability to influence the general wellbeing of an entire nation. Paying a little more attention to the physical reformation of slums will positively affect the world at large in the long run.
\end{abstract}

JOURNAL OF CONTEMPORARY URBAN AFFAIRS (2019), 3(2), 95-98.

https://doi.org/10.25034/ijcua.2018.4705

Www.ijcua.com

Copyright @ 2018 Journal Of Contemporary Urban Affairs. All rights reserved.

\section{Introduction}

A slum is defined as a heavily congested or populated, deteriorated, temporary human urban settlement characterized by substandard housing, mostly with no security, prone to crime and anti-social activities, a shortage of safe drinking water, inadequate power supply, lack of proper sanitation, and little or scarce medical and social facilities (UNHabitat, 2007; Simon et al. 2013). The slum structures are predominantly made of plastic sheets, mud walls, cardboards or tin sheets, with high potential risk to rain leakages and fire outbreaks. The slum possesses narrow and inaccessible paths, rubbish dumps, and stagnant, dirty water bodies, poor drainage systems, little or non-existent of utilities and the settlers are prone to ailments, diseases and abuses (Alagbe, 2005).

The slum household is people dwelling together with no access to basic services, comfortable living space, electricity, clean water, sanitation,

\footnotetext{
*Corresponding Author:

Faculty of Architecture, Eastern Mediterranean University, Famagusta, Cyprus.

E-mail address: 17500572@students.emu.edu.tr
} 
security, etc. The urban poverty in developing countries has resulted in congested, disorderly, and poorly erected informal slum settlements (Uduak, 2009).

Slums have been around for as long as the 19th century and one of the major causes was urbanization which was as a result of industrialization. According to the available statistics, the slum areas were first defined by the 'regimen of congestion' orchestrated by the mass movements of people in the mega cities since centuries ago. The global urbanization process, distribution and realignment of population in character, size, and networking or system, have a lot of relationships with slum formation as too many people began competing for too few dwellings and rooms due to the rapid influx of poor migrants to the cities in search of jobs and a cheap place to live (Simon et. al. 2013).

The urban population of the world has grown rapidly from 746 million in 1950 to 3.9 billion in 2014. In 2014, it was reported that 54 per cent of the world's population lives in urban areas, and predicted to increase to 61 and 66 per cent by 2030 and 2050 respectively. The projections show that the world's population could add another 2.5 billion to 3.2 billion people recorded in 2007 making it total of 5.7 billion by 2050, with close to 90 percent of the increase concentrated in Asia and Africa, according to a new United Nations report 2014. By 2050, India, China and Nigeria are projected to add 404, 292, and 212 million urban dwellers IUN Commission on population and Development, 2007; World Urbanization Prospects, 2014). The present trends of global urbanization are becoming neither orderly nor sustainable, thus, squatter and informal slum settlements are proliferating despite many urban development plans and strategies.

Slums today are becoming only places with the cheapest possible infrastructural amenities, especially accommodation (housing) adjacent most mega cities in the world. However, the slums have become settlements with the worst possible living conditions in terms of infrastructure, health care, security, economy, education, hygiene and every other condition necessary for human survival. In fact, slums are one of the most stigmatized parts of mega cities. When slum residents are thought of, they are perceived as overcrowded people not just with poor living conditions but also as people with little or no morals, norms or standards of public decency (i.e. people involved in drug abuse, crimes, violence, etc.), which is a rather harsh perception. According to UN-Habitat
2016 report, urban growth and unlawful land conversion to slums are resulting to higher crime rates, environmental degradation, and threats to global ecosystems and human existence (George, 2002). The UN-Habitat 2016 report states that the slum dwellers are estimated to grow by nearly 500 million before 2020. To this end, the chances of getting rid of slums become slimmer as time goes on not only due to the increasing population of slum dwellers, but also because of the factors which lead to its growth and the negligence of governing bodies to the present conditions of these slums. Therefore, if these slums cannot be eradicated, it is possible to create better living conditions and give a new face and identity. The aim of this paper is to discuss the reformation of slums that have been created, managing the emerging ones and to prevent the future development of others.

\section{Reformation of Slums (An Investment)}

Investing in general is defined as allocating money or a valuable resource such as time to a certain cause or action with the expectation of some benefits in the future. A lot of people invest in real estate and affordable housing, but hardly is anyone interested in investing in slums reformation probably because the benefits of doing so have not been spelled out. Slum reformation is a process of making positive changes in the present conditions of slums such as creating better road networks, providing access to basic services and amenities such as pipe borne water, electricity, better air quality, good drainages, waste management facilities and security. The reformation of slums will have a lot of positive impact on the communities at large in terms of health, economy, and security. A community with little or no crime rate and humane living conditions is to the benefit of the general populace. The reformation of slum can be attributed to some basic elements, which include urban sustainability, comprehensive, integrated and strategic visions, plans and actions (Robert, 2006). Such elements are able to effect a long lasting improvement in the economic, environmental, physical, and social conditions in slum areas. The reformation of slums with a well detailed and precise approach can revitalize slum into a more an investment platform. This will bring positive benefits to slums in the future, with more actions taken in order to improve the living conditions in slum settlements. For example, most slum settlements were created and have existed for a century, which implies that some slums have 
historical significance, but due to poor conditions of the slums, they are not perceived as potential tourist locations for economic benefits. If slums are improved or reformed and are therefore preserved like most of the world heritage sites, the poor will not be the only benefactors. Giving more people a chance for better living should be good enough reason to invest in slum reformation.

\section{Effects of negligence of slums}

Slum negligence has over a time period resulted in a lot of problems which affect primarily the slum dwellers and communities with slums on them. Below are some of the major problems faced:

Poor Housing Structure: Materials used in house construction in most slum dwellings are often materials which slum born owners find affordable and in most cases these materials are substandard, flammable, weak and even inadequate for building. Coupled with poor building materials, most lands on which slums exist are undesirable and, in some cases, prone to natural disaster such as floods, landslides and earthquakes. When such disasters occur, rescue on the hand becomes a struggle and, in some cases, impossible due to the densely packed building patterns of the homes. In Bam, Iran, poor structural quality of housing played a major factor in the earthquake-related deaths of 32,000 people in 2003. Days earlier, and earthquake of a similar magnitude killed only two people in California (Alon Ungar, 2007).

Poor Health Conditions: Cooking, sleeping, living with 13 - 14 people per $45 \mathrm{~m}^{2}$ room, as in the slums of Kolkota, India, according poses a lot of health threats for example respiratory infections. Overcrowding also increases the speed of a circulating airborne disease. Lack of inadequate safe water, lack of proper toilets, poor air quality and so on are all conditions in slums which makes the health of slum dwellers a cause for concern (Alon Ungar, 2007).

Insecure Residential Status: Lands on which most slums are situated do not belong to the slum dwellers which mean that these slum dwellers can be evicted by the government at any point in time rendering them homeless. In some countries, slum dweller's homes are demolished, which in time results in a lot of negative side effects. Alon Ungar, 2007 stated that "between 1991 and 1997, 1.5 million people were evicted from central areas of Shanghai and Beijing, respectively."

Inadequate Access to basic amenities and infrastructure: Most slum-dwellers being excluded from basic provisions like good water, proper drainages and sewers, electricity, and in some cases education, security, etc. is a known fact and the lack of the basic needs affects all aspects of an individual's life. Lack of proper street lights makes women and girls vulnerable to sexual assault, due to inadequate toilets; their environment is constantly contaminated therefore resulting in a lot of health problems. slum dwellers remain potential victims of homicide because they are excluded from the benefits of formal policing.

There are many other challenges faced by slum dwellers and the impact of these factors on nations with a high population of slum dwellers. Taking a good look at these challenges and effects of slum negligence beyond all doubt necessitates making reformation of slums a priority.

\section{Possible reformation strategies}

Over time, some strategies have been put in place to either control slum population growth or upgrade slums. These strategies have in some slums proven effective but, in some others, have been unsuccessful due to various factors, for example, poor administration or inadequate funding, as a case study.

\subsection{Proposed Slum Reformation Strategy}

The Millennium Development Goal can only be achieved by deliberate and conscious strategies, planning, and implementation of government policies to re-engineer the environmental condition, economic base, physical fabric, and social structure of the potential or existed slum settlements. The major slum challenge is substantial in term of the people to household relationship. Therefore, the restructuring of the slum settlement using comprehensive government policies on a scale with strategic planning and implementation of durable, sustainable, orderly arrangement of slum housings is very paramount. The prefabricated modular housings are suitable for the slum settlement upgrade.

Modular homes are sectional prefabricated units of living spaces which have been completely constructed and are just installed on the sites. The proposed modular homes can be built in the simplest form of a basic home and with the most cost-effective, durable, and sustainable materials.

Advantages of cheap modular homes

- $\quad$ As mentioned in earlier parts of this paper, the lands on which most slums are situated do not belong to slum dwellers, therefore there is always a risk of eviction and demolition, but in the case of this prefabricated 
homes, they can be placed in a new location thereby preventing waste of building materials and loss of properties during demolition by the government agencies.

- $\quad$ Creating modular homes one at a time helps in defining a precise road network, which in a long run makes solving other problems easier such as sewers and drainage networking, better chances of each module to access better ventilation and sunlight.

- $\quad$ Prefabricated structures make it easier for plumbing systems to be created and installed, thereby solving the problem of unsafe drinking water, eliminates water borne diseases.

- $\quad$ Prefabricated structures make it easier for sanitation systems to be created and installed, thereby solving the problem of improper waste control.

- The prefabricated housings provide appropriate housing spacing within the slum, thereby solving the problem of congestion, insecurity and disorderliness in the slum settlement.

- The modular homes will improve the identity of the slum, thus reduce the crime rate, molestation, stigmatization, violence and other anti-social vices within the slum area.

\section{Conclusions}

The reformation of the slum is an issue if taken seriously with all hands-on deck, including investors, governing bodies and the slum dwellers themselves, slums will no longer be sites with more negative remarks than positive, instead slums will become properly planned communities with as much privileges as any other planned part of an urban city. The reformation of slums anywhere is not a project that can be concluded in a hurry, but with patience and commitment, we will all contribute to developing better communities and at large a better world.

\section{Acknowledgments}

I would like to express my sincere thanks to Assist. Prof. Dr. Nazife Özay for her helpful critics and technical coordination during the study on this research. This research did not receive any specific grant from funding agencies in the public, commercial, or non-for-profit sectors.

\section{Conflict of interests}

The author declares no conflict of interest.

\section{References}

Alagbe, O. A. (2006). Combating the Challenges of Rise in Urban Slums in Cities in Developing World. A Case Study of Lagos State.

Alon Ungar, L. R. (2007). Slum Health: From Understanding to Action. Reformation and Problems.

http://eprints.covenantuniversity.edu.ng/id/ep rint/390

George, C. K. (2002). Basic principles and methods of urban and regional planning. Libro-Gem Books. Google Ref.

https://scholar.google.com/scholar?hl=en\&as_sd $t=2005 \&$ sciod $t=0 \% 2 C 5 \&$ cites $=468238564458413$ $2098 \&$ scipsc $=\& q=$ George\%2C $+C .+K .+\% 282002$ \%29.+Basic+principles+and+methods+of+urba $\mathrm{n}+$ and+regional+planning.+LibroGem+Books.\&btnG=

Simon, R. F., Adegoke, A. K., \& Adewale, B. A. (2013). Slum settlements regeneration in Lagos Mega-city: an overview of a waterfront Makoko community. International Journal of Education and research, 1(3).

http://eprints.covenantuniversity.edu.ng/id/eprin $t / 5586$

UN-Habitat. (2016, July 17). UN-HABITAT. Retrieved fromUN-HABITAT.

https://unhabitat.org/books/state-of-theworlds-cities-2010201 1-cities-for-all-bridgingthe-urban-divide/

Uduak, V. (2009). Effects of Slums on Residential Property Value: a case study of Makoko. An Unpublished Dissertation. Department of Estate Management, Covenant University, Ota Nigeria.

Un-Habitat. (2007). State of the World's Cities 2006/7; The Millennium Development Goals and Urban Sustainability: 30 years of Shaping the Habitat Agenda.

https://scholar.google.com/scholar?hl=en\&as_sd $\dagger=0 \% 2 C 5 \& q=U n-$

Habitat.+\%282006\%29.+State+of+the+World\%2 $7 s+$ Cities $+2006 \% 2 F 7 \% 3 B+$ The +Millennium+Deve lopment+Goals+and+Urban+Sustainability\%3A +30+years+of+Shaping+the+Habitat+Agenda. $+\& b+n G=$

UN Commission on Population and Development. (2007). Commission on Population and Development. Forty-first sessions. United Nations, New York, 2008.

http://www.un.org/esa/population/cpd/cpd200 8/CPD41_Resolutions_Decisions.pdf

World Urbanization Prospects (2014): The 2014 Revision-Highlights. United Nations.

https://scholar.google.com/scholar?hl=en\&as_sd $\mathrm{t}=0 \% 2 \mathrm{C} 5 \& \mathrm{q}=$ World $+\mathrm{Ur}$

banization+Prospects. $+\% 282014 \% 29 \&$ btnG= 